\begin{tabular}{|l|l|l|l|l|}
$\begin{array}{l}\text { Journal of } \\
\text { Endocrinology }\end{array}$ & M Skrzypski et al. & $\begin{array}{l}\text { Orexin in the adipo-pancreatic } \\
\text { axis }\end{array}$ & $\mathbf{2 3 8 : 2}$ & R95-R108 \\
\hline
\end{tabular}

REVIEW

\title{
The role of orexin in controlling the activity of the adipo-pancreatic axis
}

\author{
M Skrzypski', M Billert', K W Nowak' and M Z Strowski ${ }^{2,3}$ \\ 1Department of Animal Physiology and Biochemistry, Poznań University of Life Sciences, Poznań, Poland \\ 2Department of Hepatology and Gastroenterology \& The Interdisciplinary Centre of Metabolism: Endocrinology, Diabetes and Metabolism, \\ Charité-University Medicine Berlin, Berlin, Germany \\ 3Park-Klinik Weissensee, Internal Medicine - Gastroenterology, Berlin, Germany
}

Correspondence should be addressed to M Skrzypski: mskrzyps@up.poznan.pl

\section{Abstract}

Orexin A and B are two neuropeptides, which regulate a variety of physiological functions by interacting with central nervous system and peripheral tissues. Biological effects of orexins are mediated through two G-protein-coupled receptors (OXR1 and OXR2). In addition to their strong influence on the sleep-wake cycle, there is growing evidence that orexins regulate body weight, glucose homeostasis and insulin sensitivity. Furthermore, orexins promote energy expenditure and protect against obesity by interacting with brown adipocytes. Fat tissue and the endocrine pancreas play pivotal roles in maintaining energy homeostasis. Since both organs are crucially important in the context of pathophysiology of obesity and diabetes, we summarize the current knowledge regarding the role of orexins and their receptors in controlling adipocytes as well as the endocrine pancreatic functions. Particularly, we discuss studies evaluating the effects of orexins in controlling brown and white adipocytes as well as pancreatic alpha and beta cell functions.

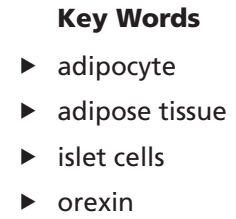

Journal of Endocrinology (2018) 238, R95-R108

\section{Introduction}

The neuropeptides termed as orexin A and B (hypocretin 1 and 2) were originally identified in rat hypothalamus as products of proteolytic cleavage of the precursor protein - preproorexin (de Lecea et al. 1998, Sakurai et al. 1998). Orexin A and orexin B are composed of 33 and 28 amino acids, respectively. Both peptides bind to two G-proteincoupled receptors termed as orexin receptor 1 (OXR1) and orexin receptor 2 (OXR2). OXR1 is equipotently activated by both peptides, whereas OXR2 has approximately tenfold selectivity for orexin B (Smart et al. 1999). Orexin receptor signaling is multifaceted; nevertheless, MAP kinases, adenyl cyclase, calcium ions and phospholipases are considered as essential intracellular molecules transmitting the signals upon orexin receptors activation (Kukkonen \& Leonard 2014, Kukkonen 2014). Early reports indicated the importance of orexins and their receptors in controlling body weight and energy homeostasis by stimulating food intake, energy expenditure (Lubkin \& Stricker-Krongrad 1998, Sakurai et al. 1998) as well as by controlling sleep-waking cycle (Lin et al. 1999). Animal studies in mice and dogs provided evidence that orexin deficiency or genetic inactivation of OXR2 cause narcolepsy (Chemelli et al. 1999, Lin et al. 1999). Furthermore, orexin A deficiency in humans is associated with narcolepsy, an excessive daytime sleepiness (Nishino et al. 2000). Since narcolepsy is associated with a higher risk of obesity and type 2 diabetes mellitus (Honda et al. 1986), it was assumed that orexin deficiency may contribute to glucose disbalance and pathophysiology of obesity (Schuld et al. 2000). Indeed, transgenic mice 
in which orexin-containing neurons are ablated, develop narcolepsy as well as obesity (Hara et al. 2001). In contrast, orexin or OXR2 overexpression in rodents protects from diet-induced obesity, improves glucose control as well as leptin sensitivity (Funato et al. 2009). It is important to acknowledge that the lack of leptin or its insensitivity are linked to pathophysiology of obesity and insulin resistance (Ingalls et al. 1950, Hummel et al. 1966, Girard 1997). Exogenous orexin A attenuates adiposity in rats and mice with diet-induced obesity, further supporting the observations in genetically modified animals (Novak \& Levine 2009, Perez-Leighton et al. 2012, 2013).

Recently, mechanisms of action through which orexin A affects energy homeostasis, glucose control and body mass were reported. Injection of orexin A into the ventromedial hypothalamus activates sympathetic nervous system, thereby promoting glucose uptake and glycogen synthesis in the skeletal muscle (Shiuchi et al. 2009). Furthermore, orexin is required to maintain motor activity (Hara et al. 2001) as well hypothalamic insulin signaling, which results in improvement of peripheral insulin sensitivity (Tsuneki et al. 2008).

Maintenance of body weight and energy homeostasis is precisely controlled by orchestration of multiple metabolic and hormonal factors released from peripheral tissues. Outside of the central nervous system, orexins and/or their receptors are expressed in the gastrointestinal tract, reproductive system, adrenal glands, heart, pancreas and adipose tissue in rodents as well as in humans (Johren et al. 2001, Nakabayashi et al. 2003, Digby et al. 2006, Skrzypski et al. 2011, Shen et al. 2013).

Orexin A circulates in blood and its levels are negatively correlated with BMI in humans (Adam et al. 2002, Tomasik et al. 2004, Baranowska et al. 2005). Plasma orexin A levels are negatively associated with insulin resistance and positively correlated with insulin sensitivity in type 2 diabetic patients (Zarifkar et al. 2017). Furthermore, plasma orexin levels are low in pregnant women who suffer from gestational diabetes mellitus (Yilmaz et al. 2013). These data suggest a functional relevance of orexin in the context of pathophysiology of obesity and type 2 diabetes.

It is well known that body weight as well as glucose control and whole body metabolism are influenced by adipose tissue, pancreatic alpha and beta cell functions and vice versa. Adipose tissue not only stores energy, however, it also produces and releases a large number of factors that participate in the regulation of energy homeostasis (Rosen \& Spiegelman 2006). Adipose tissue dysfunction is not only a hallmark of obesity; however, it strongly increases insulin resistance in type 2 diabetes mellitus (Frayn et al. 2007). Pancreatic alpha and beta cells produce and release glucagon and insulin, respectively. Insulin decreases postprandial blood glucose levels, whereas glucagon raises glucose in bloodstream (Grossman 1986). The loss of pancreatic beta cells and dysregulation of insulin and glucagon secretion contribute to impaired glucose control in type 1 and type 2 diabetes (Maedler \& Donath 2004, D'Alessio 2011).

In summary, orexin interacts with adipose tissue and with the endocrine pancreas. Orexin is linked to the pathophysiology of obesity and diabetes. Taking this into consideration, we summarize the recent studies evaluating the importance of orexins in controlling glucose and lipid metabolism.

\section{Orexin in adipose tissue}

\section{Expression of orexin and orexin receptors in white adipose tissue}

Despite some inconsistencies, it appears that both OXR isoforms are present in adipocytes. While OXR1 and OXR2 were identified in adipocytes isolated from subcutaneous and omental human fat tissue (Digby et al. 2006), others found that OXR1 but not OXR2 is present in human preadipocytes (Pino et al. 2017). Mature adipocytes isolated from abdominal subcutaneous (scab), neck subcutaneous (sc-nk) and deep neck (dp-nk) regions fail to express orexin receptors (Pino et al. 2017). However, it must be noted that the study by Digby et al. utilized adipose tissue obtained from patients undergoing elective surgery (Digby et al. 2006). In the study using differentiated adipocytes obtained from patients (sc-nk, dp-nk) as well as healthy individuals (sc-ab) heterogenous patients were included. Therefore, the discrepancies regarding the expression of orexin receptors may be due to the inclusion of heterogenous study populations. Since both studies used RT-PCR, conventional (Digby et al. 2006) vs quantitative (Pino et al. 2017), the discrepancies are rather not explained by the methodological differences. Sensitivity of both methods is comparable (Bastien et al. 2008).

We identified both Oxr1 and Oxr2 mRNA expression in rat adipocytes as well as in both, non-differentiated and fully differentiated 3T3-L1 cells (mouse embryonic fibroblast - adipocyte-like cell line) (Skrzypski et al. 2011). mRNA expression and protein production of OXR1 in rat adipocytes was reported by Shen et al. (2013). Of note, 
the authors described reduced $O X R 1$ protein production in obese rats as compared to non-obese animals (Shen et al. 2013). OXR1 and OXR2 mRNA are also expressed in porcine preadipocytes (Wojciechowicz et al. 2016). Furthermore, both orexin receptors are present in porcine subcutaneous and visceral adipose tissue as well as in mature porcine visceral adipocytes on mRNA and protein levels. Noteworthy, the expression of OXR1 is higher compared to OXR2 in both investigated fat depots and isolated adipocytes (Pruszynska-Oszmalek et al. 2018).

Preproorexin mRNA is expressed in white adipose tissue in mice (Zhang et al. 2010b). However, in this study, animals were fed diet containing lard (5 or $45 \%$ ); therefore, it cannot be excluded that this diet could contribute to induction of preproorexin mRNA in adipose tissue. In support of this notion, mice fed high-lard diet (45\%) displayed approximately two-fold higher expression of preproorexin, compared to animals fed chow diet supplemented with $5 \%$ lard. Stimulation of preproorexin mRNA expression by high-fat diet is supported by the results of a study performed in rats (Barson et al. 2012). Barson and colleagues showed that lard (41\%) diet upregulates preproorexin expression in the perifornical lateral hypothalamus.

There is evidence indicating that lard oil induces endoplasmatic reticulum (ER) stress in rat adipose tissue (Nivala et al. 2013). Importantly, ER stress stimulates the activity of numerous transcription factors (Jiang et al. 2016), which suggests that ER may be relevant in conferring lard diet-induced preproorexin expression. Nevertheless, due to heterogenic nature of adipose tissue, which is composed of many cell types including preadipocytes adipocytes, macrophages and fibroblasts (Altintas et al. 2011), the cellular source of preproorexin mRNA in fat tissue is unknown. Studies utilizing isolated murine adipocytes should answer the question whether preproorexin is present in adipocytes. By contrast, preproorexin mRNA is absent in human adipose tissue (Digby et al. 2006). Overall, the majority of studies showed that white rodent and porcine adipocytes express both isoforms of orexin receptors. By contrast, expression of orexin receptors in human mature adipocytes requires further investigations.

\section{The role of orexins in white preadipocytes}

Using 3T3-L1 preadipocytes, we and others reported that orexin A stimulates, whereas orexin B suppresses preadipocytes proliferation in vitro (Zwirska-Korczala et al.
2007, Skrzypski et al. 2012). Orexin A can also enhance proliferation of rat primary preadipocytes as well as NIH 3T3 cells. Both orexin A and B can augment porcine preadipocytes growth (Wojciechowicz et al. 2016). Orexin A protects 3T3-L1 preadipocytes from apoptosis induced either by serum deprivation or by palmitic acid administration (Skrzypski et al. 2012). The promitogenic and antiapoptotic properties of orexin A (Fig. 1) are mediated via ERK1/2-dependent mechanism (Skrzypski et al. 2012).

The role of orexins in controlling rodent preadipocytes differentiation into mature adipocytes is not completely understood. While Oxr1 mRNA expression increases during differentiation of 3T3-L1 preadipocytes (Skrzypski et al. 2011), orexin A fails to affect differentiation of rat or 3T3-L1 preadipocytes (Skrzypski et al. 2012). However, a recent study showed that orexin A has ability to increase Pparg2 expression in undifferentiated 3T3-L1 cells in vitro (Shen et al. 2013). PPARG2 plays a prominent role in inducing adipogenesis (Tontonoz et al. 1994a,b); therefore, the influence of orexin A on rodent preadipocytes differentiation needs to be studied in a more detailed fashion.

In contrast to rodents, we recently showed that both orexin A and B can enhance isolated porcine preadipocytes differentiation as judged by the increased lipid accumulation and the expression of proadipogenic genes: PPARG2, C/EBPA and C/EBPB (Wojciechowicz et al. 2016). Studies evaluating the role of orexins in the context of human adipogenesis are scarce. To our knowledge, there is only one in vitro study available to date that reported an inability of orexin A to induce the expression of adipogenic markers in preadipocytes isolated from sc-ab and sc-nk adipose tissue (Pino et al. 2017). Overall, orexins may stimulate or suppress preadipocytes proliferation and differentiation in a species-specific manner. While in rodents, orexin A stimulates preadipocytes growth and protects them from apoptosis, orexin B suppresses cell proliferation. By contrast, orexins A and B induce proliferation and differentiation of preadipocytes isolated from pigs. In humans, however, orexin A rather fails to stimulate the differentiation of preadipocytes.

\section{The role of orexins in regulating mature white adipocytes functions and adipokines production}

Orexin A but not orexin B reduces glycerol release and the expression of hormone-sensitive lipase (HSL) in human 


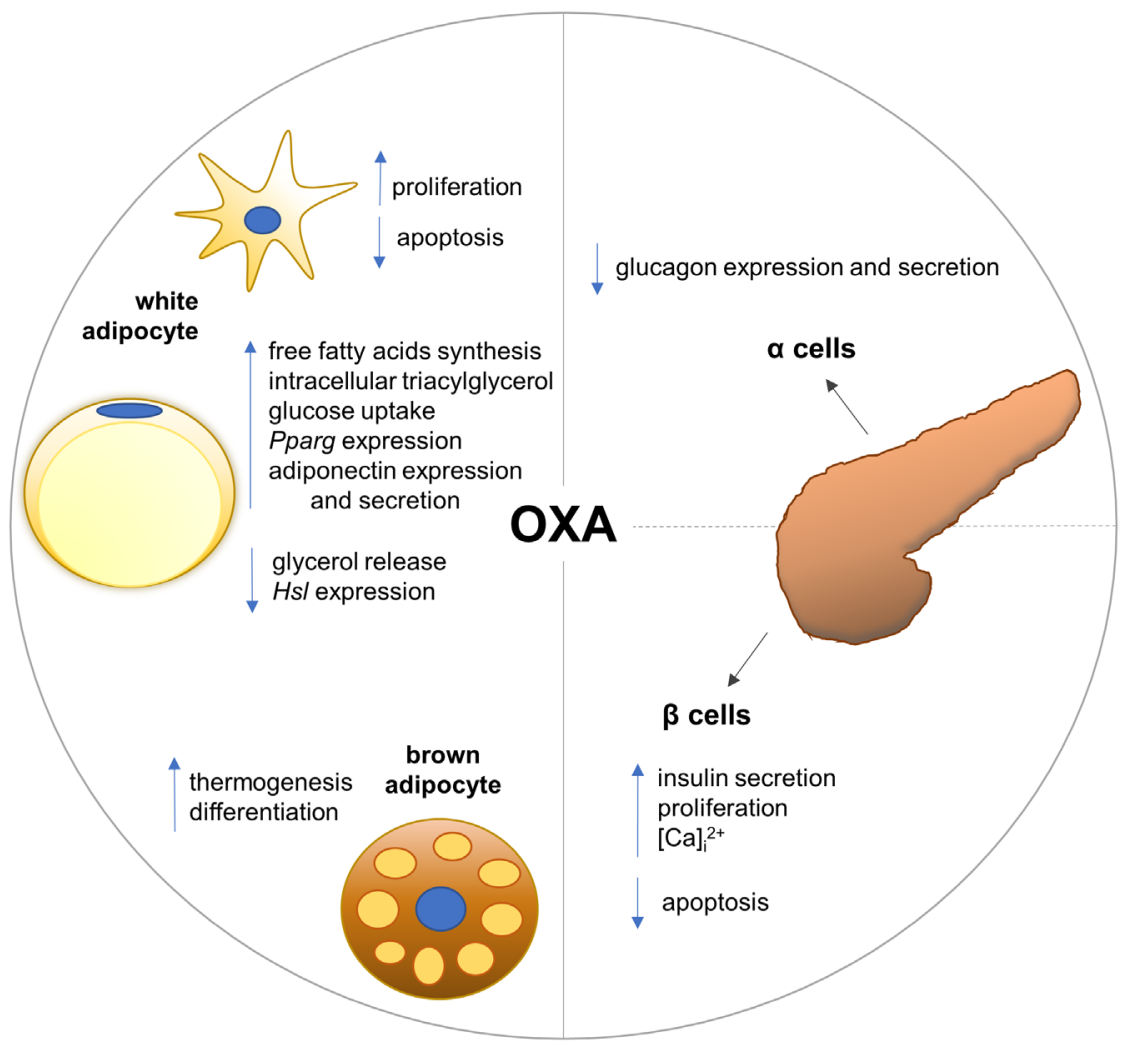

\section{Figure 1}

Summary of the orexin A (OXA) effects on preadipocytes and mature adipocytes of white adipose tissue, brown adipose tissue and endocrine cells of pancreatic islets. A full color version of this figure is available at https://doi. org/10.1530/JOE-18-0122. omental adipose tissue in vitro (Digby et al. 2006). Orexin A stimulates free fatty acid synthesis in freshly isolated rat adipocytes and increases intracellular triacylglycerol content in 3T3-L1 adipocytes. Furthermore, orexin A suppresses glycerol release as well as Hsl mRNA expression in 3T3-L1 adipocytes (Skrzypski et al. 2011), which is consistent with findings reported in humans (Digby et al. 2006). Suppression of lipolysis by orexin A but not orexin B was also reported in isolated porcine adipocytes (Pruszynska-Oszmalek et al. 2018). Overall, these in vitro results suggest that orexin A exerts its lipogenic and antilipolytic activities by acting directly on adipocytes. Nevertheless, it must be noticed that recent human studies revealed that orexin A has no effects on lipolysis in fat tissue explants derived from the neck or abdominal regions (Pino et al. 2017). As discussed earlier, the same study also showed that differentiated adipocytes lack orexin receptors, which may explain the lack of effects of orexin A on lipolysis in fat tissue explants. Thus, orexin A may affect lipid metabolism in rodents and pigs; however, there is a lack of convincing evidences in humans.

Our laboratory provided evidence that activation of orexin receptors results in increased rate of glucose uptake in differentiated 3T3-L1 mature adipocytes and isolated rat primary adipocytes. This process requires activation of PI3-K/PKB pathway that in turn leads to enhanced translocation of the glucose transporter GLUT4 to the plasma membrane (Skrzypski et al. 2011). Orexin A enhances glucose uptake by stimulating GLUT4 expression in porcine adipocytes (Pruszynska-Oszmalek et al. 2018). GLUT4 plays a prominent role in insulin-induced glucose uptake and its selective depletion in adipose tissue causes insulin resistance (Abel et al. 2001).

A recent study reported that orexin A has the ability to increase Glut4 mRNA expression in 3T3-L1 adipocytes (Shen et al. 2013), concurring our findings. Stimulation of Glut4 mRNA expression by orexin A was attenuated by pharmacological blockade of MAP kinases members (ERK1/2, JNK, p38) or OXR1 (Shen et al. 2013). Overall, these data suggest that orexin A may stimulate glucose uptake in adipocytes by inducing GLUT4 translocation into the plasma membrane via PI3-K/PKB-dependent mechanism.

Human and rodent data show that orexin A increases PPARG2 expression in adipocytes (Digby et al. 2006, Skrzypski et al. 2011, Shen et al. 2013). The lipogenic potency of orexin A can be attenuated by blocking PPARG expression and activity. However, Shen et al. found that orexin A can activate multiple MAP kinases in 3T3-L1 adipocytes and their inhibition was sufficient to block orexin A-induced lipogenesis, Glut4 and Pparg2 expression (Shen et al. 2013). Taken together, PPARG and MAP kinases are required for orexin A-induced lipogenesis. 
Adipocytes produce and release a variety of hormones. Among them are adipokines that strongly influence glucose metabolism, insulin sensitivity and play a role in the pathophysiology of obesity (Ouchi et al. 2011). We reported that orexin A can stimulate expression and secretion of adiponectin in 3T3-L1 adipocytes (Skrzypski et al. 2011). Furthermore, orexin A upregulated plasma concentrations of adiponectin in lean, obese and T2DM animals, and increased FGF-21 levels in animals with T2DM (Kaczmarek et al. 2017). Notably, there is convincing evidence indicating that adiponectin promotes insulin sensitivity (Yamauchi et al. 2001, Awazawa et al. 2011) and the lack or low levels of adiponectin are relevant in the context of pathophysiology of T2DM (Lindsay et al. 2002). In vivo, orexin A can reduce leptin levels in rats and mice (Switonska et al. 2002, Park et al. 2015). By contrast orexin A stimulates leptin secretion and expression in porcineisolated adipocytes (Pruszynska-Oszmalek et al. 2018).

In a rat model of T2DM and obesity, we reported that treatment with orexin A for 4 weeks decreases fasting levels of glucose in these animals (Kaczmarek et al. 2017). Furthermore, orexin A-treated T2DM rats had improved glucose tolerance. Obese and T2DM animals treated with orexin A had reduced plasma levels of proinflammatory cytokines TNF-a, resistin and visfatin (Kaczmarek et al. 2017). These three cytokines contribute to insulin resistance, impair insulin secretion and play a role in pathophysiology of obesity (Stofkova 2010, Makki et al. 2013).

Since all of these hormones are produced and secreted by adipocytes (Arita et al. 1999, Muise et al. 2008), it is possible that orexin A can improve glucose control and insulin sensitivity by influencing the release of these pro- and anti-inflammatory adipokines in a favorable manner. However, it remains not clear whether orexin A modulates adipokines levels directly or by normalizing other metabolic parameters such as blood glucose or body weight. Notably, reduction of body weight is paralleled by the reduction of circulating proinflammatory cytokines in humans and animals (Ziccardi et al. 2002, Rivera et al. 2008, Tajik et al. 2013). On the other hand, as already discussed before, orexin A stimulates adiponectin expression and secretion in vitro. Therefore, modulation of pro- and/ or anti-inflammatory cytokines may be complex and encompass direct and indirect interaction with several target tissues such as adipocytes. Through these multiple interactions, orexin may attenuate metabolic diseases including obesity.

Overall, a significant part of data regarding the function and expression of orexin receptors in adipose tissue came from in vitro studies; therefore, the physiological relevance of these findings needs to be confirmed in vivo. Since enhanced orexin 2 receptor signaling or orexin overexpression are associated with reduced body weight in animals with diet-induced obesity (Funato et al. 2009), lipogenic activities of orexin reported in in vitro studies are rather not relevant in vivo. It appears that the direct effects of orexin A on adipocytes are overridden by the possible interaction with antilipogenic factors in vivo. For example, orexin A can rise corticosterone levels in vivo (Malendowicz et al. 1999). Glucocorticoids can stimulate lipolysis in adipocytes (Xu et al. 2009). In addition, orexin potentiates physical activity and energy expenditure (Lubkin \& Stricker-Krongrad 1998, Perez-Leighton et al. 2012), which may counteract orexin A-induced lipid accumulation.

On the other hand, it appears likely that orexin A contributes to changes of the morphology of white fat tissue via stimulation of preadipocytes proliferation and through inhibition of apoptosis. Of central importance in this context is the transcriptional receptor factor PPARG, which has the ability to increase insulin sensitivity and to enhance glucose uptake and adiponectin expression (Maeda et al. 2001, Liao et al. 2007, Sharma \& Staels 2007).

Activation of PPARG leads to increased number of small preadipocytes. These small adipocytes are, in contrast to large adipocytes, more insulin sensitive (de Souza et al. 2001). Newly differentiated small adipocytes have a potent storage capacity for lipids. This ability of small adipocytes is responsible for reduction of circulating FFA. It is well known that FFA deteriorates insulin sensitivity by several mechanisms: inhibition of insulin-stimulated glucose uptake, suppression of glycogen synthase activity (Boden 1999) and promotion of inflammation (Sears \& Perry 2015). Therefore, reduction of circulating FFA contributes to improved insulin sensitivity in obesity and T2DM (Daniele et al. 2014).

\section{Orexin and brown adipose tissue}

In contrast to white adipocytes, which serve mainly as energy storage in addition to producing of cytokines, brown fat cells are able to generate heat (Smith \& Horwitz 1969). Initially, it was thought that the presence of BAT is restricted to the newborns only; however, later studies showed that BAT is present in adult humans and of the amounts of BAT are inversely correlated with BMI (Cypess et al. 2009). Activation of brown adipose tissue promotes oxidative metabolism and energy expenditure 
(Ouellet et al. 2012). These processes are conferred via UCP1 protein (Nicholls et al. 1978). The capacity of brown adipocytes to generate heat is precisely controlled by orchestration of environmental and hormonal factors as well as the sympathetic nervous system (Richard et al. 2010). Orexin receptors are highly expressed in brain regions responsible for thermoregulations such as raphe pallidus (Marcus et al. 2001). Furthermore, it was found that cold stress leads to stimulation of preproorexin mRNA expression in lateral hypothalamic area (Ida et al. 2000), indicating that orexin may be involved in controlling body temperature. Concordantly, it was found administration of orexin A into the lateral cerebral ventricle stimulates sympathetic firing rate and increases colonic temperature (Monda et al. 2001). In line with these results, injection of orexin A into the rostral raphe pallidus induces thermogenesis in BAT (Tupone et al. 2011). Elevation of body temperature was also detected after orexin A administration into the fourth ventricle in rats (Zheng et al. 2005). Another study found that mice with neuron-specific orexin deficiency have attenuated stressinduced hyperthermia and reduced UCP1 expression in BAT (Zhang et al. 2010a). In mice, orexin neurons are also required for prostaglandin E2-induced fever as well as for the adaptation to environmental cooling (Takahashi et al. 2013). In line with these results, ablation of hypothalamic orexin neurons results in reduced BAT thermogenesis (Mohammed et al. 2014). Others reported that central administration of orexin A promotes thermogenesis; however, these effects are not mediated via changes in UCP1 expression in BAT (Yoshimichi et al. 2001, Russell et al. 2002). Another study showed that orexin is involved in conferring thermogenic effects of bone morphogenetic protein 8B (BMP8B) (Martins et al. 2016). This study found that intracerebroventricular injection of BMP8B induces thermogenesis and UCP1 expression in BAT, which is associated with increased preproorexin mRNA expression in the lateral hypothalamic area in rats. These effects were reversed in mice lacking orexin or OXR1 (Martins et al. 2016).

In contrast to thermogenic properties of orexin $\mathrm{A}$, it was found that pharmacological blockade of OXR1 receptor by the antagonist SB-334867-A leads to increased thermogenesis via upregulation of $U c p 1$ in BAT in $o b / o b$ mice (Haynes et al. 2002). Furthermore, a recent study demonstrated that orexin-deficient mice have higher amounts of BAT deposits (Ramanathan \& Siegel 2014). Results in experiments with orexin-null mice with diet-induced obesity suggest that orexin $\mathrm{A}$ is antiadipogenic (Sellayah et al. 2011). Increased body weight in mice lacking orexin was associated with enhanced metabolic efficiency but not with increased food consumption. Additionally, orexin-depleted obese mice had reduced energy expenditure and decreased $\mathrm{O}_{2}$ consumption. In BAT isolated from orexin A-null mice, several thermogenic genes such as $P g C-1 a$, Tfam and Ucp1 were downregulated when compared to the levels detected in BAT obtained from WT animals. Furthermore, mice with orexin deficiency showed reduced Pparg expression and triacylglycerol content in $\mathrm{BAT}$, suggesting that orexin A stimulates the differentiation of brown preadipocytes. The relevance of orexin in regulating brown adipogenesis was shown in studies utilizing orexin-deficient mice. These animals had lipoatrophy of intrascapular BAT. Direct positive effects of orexin on brown preadipocytes differentiation were confirmed by in vitro experiments showing the ability of orexin to induce differentiation of mesenchymal C3H10T1/2 cells, HIB1B cells (brown preadipocytes cell line) as well as primary murine brown preadipocytes (Sellayah et al. 2011). Mechanisms of orexin-enhanced brown preadipocytes differentiation include OXR1-mediated phospholipase C and p38 MAP kinase activation (Sellayah et al. 2011, Sellayah \& Sikder 2012). In summary, orexin A is required for adipogenesis of BAT in rodents. Furthermore, these results allow claiming that the loss of BAT in orexin-depleted mice may be a link between orexin deficiency and obesity. In agreement with this hypothesis, application of orexin can reverse BAT dysfunction caused by aging in rodents, thereby leading to improved glucose control and body weight loss (Sellayah \& Sikder 2013). By contrast, there is evidence indicating that orexin A fails to stimulate the differentiation of brown preadipocytes as well as the expression of thermogenic genes in preadipocytes and differentiated brown fat cells obtained from human individuals (Pino et al. 2017). Therefore, thermogenic properties of orexin A could be also species specific.

\section{Orexin in the endocrine pancreas}

\section{Expression of orexins and orexin receptors in endocrine cells of pancreatic islets}

A vast part of experiments evaluating the presence of orexin system in endocrine pancreas was performed using isolated rat pancreatic islets. Oxr1 and Oxr2 mRNAs is present in rat pancreatic islets (Nowak et al. 2005). On the protein level, the presence of OXR1, but not OXR2, was reported in protein lysates derived from rat and murine 
islets (Goncz et al. 2008, Park et al. 2015). Thus, expression of OXR2 in pancreatic islets may be restricted to mRNA level, only.

Double immunofluorescence staining revealed that OXR1 is present in glucagon- and insulin-immunoreactive cells in rats (Ouedraogo et al. 2003, Goncz et al. 2008, Adeghate et al. 2010). In agreement with these findings, OXR1 protein production was detected in rat insulinoma INS-1 and hamster glucagonoma InR-G9 cell lines (Goncz et al. 2008, Chen et al. 2013). It is important to note that OXR1 was also detected in intrapancreatic nerves in rats and guinea pigs (Kirchgessner \& Liu 1999, Adeghate et al. 2010). The complexity of orexin system in pancreatic islets is supported by studies showing the immunoreactivity of orexin A in endocrine cells of islet. Orexin A was found in pancreatic beta cells in the rat and guinea pig (Kirchgessner \& Liu 1999, Adeghate et al. 2010) and in glucagon-producing alpha cells in rat islets (Goncz et al. 2008). Furthermore, orexin A immunoreactivity was also detected in $65.8 \%$ of human beta and $9.8 \%$ of alpha cells (Nakabayashi et al. 2003). Others confirmed that only orexin A is present in human beta and PP but not in alpha cells and delta cells (Ehrstrom et al. 2005). These two studies used different anti-orexin A antibodies. Several studies investigated the impact of diabetes on OXR1 expression in pancreatic islets. Adeghate et al. reported an increased number of OXR1-positive cells in pancreatic islets in STZ diabetic and T2DM GotoKakizaki rats as compared to Wistar rats (Adeghate \& Hameed 2005, Adeghate et al. 2010). Noteworthy, healthy animals express OXR1 mostly in insulin-immunoreactive cells, whereas diabetic animals mostly in glucagonimmunoreactive cells. The authors of this study suggest that, at least in type 1 diabetic rats, increased expression of OXR1 in pancreatic islets may be triggered by low intracellular glucose content, which occurs in the majority of cell in the absence of insulin (Adeghate et al. 2010). In summary, in pancreatic beta cells OXR1 but not OXR2 is present on protein level. Similar to beta cells, alpha cells also produce OXR1 protein, whereas OXR2 is absent. Therefore, these findings indicate that only OXR1 can by relevant in controlling functions of alpha and beta cells including insulin and glucagon secretion. Nevertheless, it must be considered that protein levels of OXR2 could be present in endocrine cells of pancreatic islets; however, the antibodies are not sensitive enough to identify OXR2 in these cells. Finally, it is worth to notice, that, in addition to alpha and beta cells, pancreatic islets contain many other endocrine cells such as delta, epsilon and PP, which produce somatostatin, ghrelin and pancreatic polypeptide, respectively (Steiner et al. 2010). Expression and distribution of orexin receptors in these cells remain to be investigated.

\section{Regulation of orexin secretion in humans and rodents}

The secretion of insulin and glucagon from pancreatic beta and alpha cells is precisely regulated by glucose (MacDonald et al. 2005, Walker et al. 2011). Ouedraogo et al. found that orexin A secretion form isolated rat pancreatic islets increases at low glucose $(2.8 \mathrm{mM})$, while at high concentration of glucose $(16.7 \mathrm{mM})$, orexin A release decreases (Ouedraogo et al. 2003). In contrast, there was no difference in orexin A secretion from rat islets at 2.8, 10 and $16.7 \mathrm{mM}$ glucose (Arafat et al. 2014), suggesting that orexin A secretion from pancreatic islets is glucose independent. On the other hand, application of glucagon reduces orexin A secretion during static incubation of rat islets at low as well as high glucose concentrations. Reduction of orexin A release by glucagon was not reversed by co-incubation with insulin secretion blocker diazoxide (Arafat et al. 2014), suggesting that inhibition of orexin A release by glucagon is rather insulin independent. Nevertheless, co-incubation with anti-insulin antibody inhibits orexin A secretion from rat pancreatic islets, which suggests that insulin stimulates orexin A secretion.

The relevance of glucagon in suppressing orexin A levels was also confirmed in vivo. We reported that administration of glucagon reduces circulating levels of orexin A in healthy lean and type 1 diabetic humans as well as in obese non-diabetic mice (Arafat et al. 2014). Furthermore, the lack of any correlation between timedependent changes of glucose and orexin A levels confirms that in the peripheral tissues, glucose is probably not relevant in modulating orexin A secretion from pancreatic islets and its levels in blood circulation. Overall, considering opposite effects of orexin A and glucagon on blood glucose levels (reduction vs rise), glucagon may prevent an excessive decline of blood glucose concentration in response to orexin A. Furthermore, glucagon can stimulate lipolysis (Heckemeyer et al. 1983, Perea et al. 1995), whereas orexin A suppresses this process (Digby et al. 2006, Skrzypski et al. 2011). Thus, inhibition of orexin A secretion by glucagon may be relevant event for orexin A-modulated lipid metabolism. Furthermore, it can partially explain the lack of orexin A at promoting lipogenesis in vivo. 
As compared to orexin A, little is known regarding orexin B expression in pancreatic islets. Orexin B is detectable in pancreatic beta cells in rat islets as well as in nerves in the intrapancreatic blood vessels (Adeghate \& Hameed 2011). In contrast to orexin A, nothing is known about the modulation of orexin B production and secretion from pancreatic islets.

\section{The role of orexins in controlling insulin and glucagon secretion}

Acute subcutaneous injection as well as prolonged administration of orexin A and orexin B leads to increase in blood insulin levels in rats (Nowak et al. 2000, Switonska et al. 2002). In vitro perfusion study showed that orexin A enhances insulin secretion from rat pancreas (Nowak et al. 2000). Stimulation of insulin secretion by orexin A was confirmed by an independent study conducted on perfused rat pancreas by our laboratory (Goncz et al. 2008). In line with these data, Chen et al. reported a significant increase in insulin secretion from rat INS-1 insulinoma cells incubated with orexin A (Chen et al. 2013). In addition, orexin B is able to stimulate insulin release from pancreatic tissue fragments derived from healthy and STZ diabetic rats (Adeghate \& Hameed 2011). Elevation of plasma insulin levels was also reported in humans during orexin A infusion (Ehrstrom et al. 2005).

Park et al. reported that orexin A stimulates insulin secretion form murine pancreatic islets in vitro as well as in in vivo (Park et al. 2015). Adenylate cyclase and ryanodine receptors confer the effects of orexin A on insulin exocytosis (Park et al. 2015). In addition, we recently reported that orexin A-stimulated insulin secretion from INS-1E cells can be blocked by nonspecific transient receptor potential channels blockers such as $\mathrm{La}^{3+}$ and ruthenium red (Skrzypski et al. 2016). Thus, orexin A stimulation of insulin secretion is mediated via cAMPand calcium-dependent mechanisms.

It must be pointed out that contradictory data regarding the role of orexin in regulating insulin secretion were reported. Tsuneki et al. found that exogenous orexin A lowers blood glucose levels in fasted healthy and STZ diabetic mice without affecting insulin concentration (Tsuneki et al. 2002). Ehrstrom et al. reported in rats that insulin levels were unaffected by exogenous orexin A (Ehrstrom et al. 2004). The lack of orexin A effects on insulin secretion during static incubation of rat pancreatic islets was also reported by Colombo et al. (2003).
Ouedraogo et al. reported that orexin A can reduce insulin secretion from isolated rat islets (Ouedraogo et al. 2003).

Regarding the regulation of glucagon secretion by orexin A, more consistent findings were reported. Orexin A suppressed glucagon secretion from in situ-perfused rat pancreas, isolated rat pancreatic islets and glucagonproducing hamster InR1-G9 cell line (Goncz et al. 2008). Very recent work demonstrated that orexin A decreases glucagon secretion from porcine pancreatic islets in vitro (Sassek et al. 2017). On the other hand, others found that orexin A stimulates glucagon release from rat pancreatic islets (Ouedraogo et al. 2003). Human study showed no changes in plasma glucagon levels during orexin A infusion (Ehrstrom et al. 2005). It is difficult to explain these inconsistencies. Nevertheless, as discussed in the work by Göncz et al., it cannot be excluded that different experimental settings and methods of glucagon evaluation (ELISA vs RIA) could contribute to these discrepancies (Goncz et al. 2008).

Orexin B enhanced glucagon release from pancreatic tissue fragments derived from non-diabetic rats, without any effects in tissue fragments derived from STZ diabetic rats (Adeghate \& Hameed 2011). In InR1-G9 cells, orexin A reduced glucagon mRNA expression via PI3-K/PKB- and FOXO-1-dependent pathways (Goncz et al. 2008).

Taken together, 20 years of studies addressing the role of orexins in controlling insulin secretion provided inconsistent results. Nevertheless, the majority of studies showed that orexin A stimulates insulin exocytosis from beta cells in vitro and in vivo, in different species including rats, mouse and pigs as well as in insulin-producing cell lines. Furthermore, recent studies addressing mechanism by which orexin A induces insulin release showed that stimulation of calcium and cAMP, two important second messengers involved in insulin exocytosis, is relevant in this context (Prentki \& Matschinsky 1987). Thus, these results strongly support the conclusion that orexin A belongs to insulin secretagogues.

\section{The effects of orexin on proliferation and apoptosis of beta cells}

We and others reported that orexin A stimulates proliferation of insulin-producing rat INS-1 and INS-1E beta cells (Chen et al. 2013, Skrzypski et al. 2016). OXR1activated PI3-K/PKB-dependent mechanism appears to confer the effects of orexin A on beta cell proliferation (Chen et al. 2013). Using a pharmacological inhibitor of ERK1/2 signaling, we showed that this pathway is relevant 
in mediating the proliferative activity of orexin $\mathrm{A}$ in INS-1E cells (Skrzypski et al. 2016). Taken together, PI-3K and ERK1/2 pathway are involved in orexin A-induced insulin-producing cell proliferation.

Furthermore, orexin A is able to protect INS-1 cells from apoptotic death induced by serum depravation (Chen et al. 2013). This effect is mediated via OXR1 and PKB (Chen et al. 2013). Moreover, orexin A can protect INS-1E cells and freshly isolated rat pancreatic islets from TNF-alpha and palmitic acid-induced apoptosis (Kaczmarek et al. 2017). A recent study showed that antiapoptotic effects of orexin A in endocrine cells of pancreas are not restricted to rodents, only. It was shown that, by interacting with porcine isolated pancreatic islets, orexin A stimulates islets viability and protects them from staurosporine-induced apoptosis via ERK1/2-dependent signaling (Sassek et al. 2017).

The late stage of T2DM is characterized by the loss of beta cells, increased insulin resistance and inadequate secretion of insulin (Prentki \& Nolan 2006). Moreover, the ratio of pancreatic alpha to insulin-producing cells increases in T2DM patients (Henquin \& Rahier 2011). Several nongenetic animal models of T2DM are known, one of which can be generated using a single injection of STZ together with prolonged HFD feeding (Luo et al. 1998, Reed et al. 2000). In this animal model, induction of diabetes by STZ/HFD leads to beta cell loss and hyperglycemia. Alpha cell mass increases in these diabetic animals, reflecting morphological abnormalities of the endocrine pancreas reported in humans. Continuous subcutaneous infusion of orexin A for 4 weeks into rats with STZ/HFD (T2DM) diabetes attenuates the reduction of beta cell area and enhanced insulin mRNA expression control (Kaczmarek et al. 2017). In contrast, orexin A reduces alpha cells area and glucagon mRNA expression in T2DM rats. In agreement with the previous studies showing that orexin promotes insulin sensitivity (Funato et al. 2009) and increases glucose uptake (Skrzypski et al. 2011), we found that orexin A-treated rats displayed attenuated insulin resistance and reduced hyperglycemia (Kaczmarek et al. 2017).

Overall, these data suggest that orexin receptor signaling in pancreatic alpha and beta cells may protect from pancreatic islet dysfunctions and beta cell loss in T2DM. This notion is supported by our findings showing that cleaved caspase 3 production and activity in isolated islets are attenuated in orexin A-treated T2DM animals comparing vehicle-treated rats (Kaczmarek et al. 2017). Nevertheless, it should be noticed that another study addressing the role of orexin system components in pancreatic islets showed that mice lacking orexin have reduced number of cleaved caspase-3-positive cells in pancreatic islets (Adeghate et al. 2010). The same study showed that induction of type 1 diabetes mellitus in rats is associated with increased number of OXR1- as well as cleaved caspase3-positive cells in pancreatic islets (Adeghate et al. 2010). Activation of different caspase cascades including caspase 3 plays a prominent role in stimulating beta cells apoptosis (Hui et al. 2004). Thus, attenuation of cleaved caspase 3 production in orexindeficient mice and positive correlation between OXR1 and cleaved caspase 3 suggests potential contribution of orexin receptor in beta cell loss. On the other hand, in the light of our data showing that orexin receptor signaling suppresses beta cell death (Kaczmarek et al. 2017), it cannot be excluded that upregulation of OXR1 in apoptotic cells is a part of cellular self-defense system.

Since both, T1DM and T2DM, are characterized by beta cell loss (Cnop et al. 2005) orexin receptor signaling may be a potential therapeutic target relevant for in improving beta cell functions.

\section{Concluding remarks}

In summary, orexin A promotes fibroblasts/ preadipocytes cell proliferation but not the differentiation into mature adipocytes by acting on rat and murine adipocytes. In contrast, orexin B suppresses 3T3-L1 preadipocytes growth. Both orexin isoforms stimulate differentiation and proliferation of porcine preadipocytes, suggesting that species differences exist. In mature rodent and porcine adipocytes, orexin A stimulates glucose uptake, lipid accumulation and adiponectin production. In humans, OXR1 and OXR2 are expressed in differentiated white adipocytes. However, recent data indicate that OXR1 but not OXR2 is present in preadipocytes, whereas both receptors are absent in mature adipocytes. Furthermore, orexin A suppresses lipolysis and stimulates PPARG expression in human and rodent adipocytes. Furthermore, orexin A modulates brown adipose tissue formation and functions in rodents, which is relevant in promoting energy expenditure, negative energy balance and protection from obesity. Concluding the role of orexin A in endocrine pancreas, current vast part of data indicate that orexin A stimulates insulin secretion while it inhibits glucagon release. Furthermore, orexin A stimulates insulin-producing INS-1 and INS-1E cell proliferation. These effects are mediated via OXR1. 
Orexin A can suppress beta cell loss in type 2 diabetic rats. Activation of orexin protects from diet-induced obesity and improves glucose control and beta cells function in animals. In summary, orexin could represent a novel player in regulating the adipo-pancreatic axis. The complex interaction of orexin with the adipo-pancreatic axis could be relevant in the context of obesity and diabetes.

\section{Declaration of interest}

The authors declare that there is no conflict of interest that could be perceived as prejudicing the impartiality of this review.

\section{Funding}

This work was supported by the Polish National Science Centre (grant no. 2011/03/N/NZ4/02965) to M Skrzypski).

\section{References}

Abel ED, Peroni O, Kim JK, Kim YB, Boss O, Hadro E, Minnemann T, Shulman GI \& Kahn BB 2001 Adipose-selective targeting of the GLUT4 gene impairs insulin action in muscle and liver. Nature $\mathbf{4 0 9}$ 729-733. (https://doi.org/10.1038/35055575)

Adam JA, Menheere PP, van Dielen FM, Soeters PB, Buurman WA \& Greve JW 2002 Decreased plasma orexin-A levels in obese individuals. International Journal of Obesity and Related Metabolic Disorders 26 274-276. (https://doi.org/10.1038/sj.ijo.0801868)

Adeghate E \& Hameed R 2005 Immunolocalization of orexin-1 receptor the pancreas of normal and diabetic rats. Biogenic Amines 19 347-379. (https://doi.org/10.1163/156939105774647402)

Adeghate E \& Hameed R 2011 Mechanism of orexin B-stimulated insulin and glucagon release from the pancreas of normal and diabetic rats. Pancreas 40 131-136. (https://doi.org/10.1097/ MPA.0b013e3181f74b4b)

Adeghate E, Fernandez-Cabezudo M, Hameed R, El-Hasasna H, El Wasila M, Abbas T \& Al-Ramadi B 2010 Orexin-1 receptor co-localizes with pancreatic hormones in islet cells and modulates the outcome of streptozotocin-induced diabetes mellitus. PLoS ONE $\mathbf{5}$ e8587. (https:// doi.org/10.1371/journal.pone.0008587)

Altintas MM, Azad A, Nayer B, Contreras G, Zaias J, Faul C, Reiser J \& Nayer A 2011 Mast cells, macrophages, and crown-like structures distinguish subcutaneous from visceral fat in mice. Journal of Lipid Research 52 480-488. (https://doi.org/10.1194/jlr.M011338)

Arafat AM, Kaczmarek P, Skrzypski M, Pruszynska-Oszmalek E, Kolodziejski P, Adamidou A, Ruhla S, Szczepankiewicz D, Sassek M, Billert M, et al. 2014 Glucagon regulates orexin A secretion in humans and rodents. Diabetologia 57 2108-2116.

Arita Y, Kihara S, Ouchi N, Takahashi M, Maeda K, Miyagawa J, Hotta K, Shimomura I, Nakamura T, Miyaoka K, et al. 1999 Paradoxical decrease of an adipose-specific protein, adiponectin, in obesity. Biochemical and Biophysical Research Communications 257 79CC83. (https://doi.org/10.1006/bbrc.1999.0255)

Awazawa M, Ueki K, Inabe K, Yamauchi T, Kubota N, Kaneko K, Kobayashi M, Iwane A, Sasako T, Okazaki Y, et al. 2011 Adiponectin enhances insulin sensitivity by increasing hepatic IRS-2 expression via a macrophage-derived IL-6-dependent pathway. Cell Metabolism 13 401-412. (https://doi.org/10.1016/j.cmet.2011.02.010)
Baranowska B, Wolinska-Witort E, Martynska L, Chmielowska M \& Baranowska-Bik A 2005 Plasma orexin A, orexin B, leptin, neuropeptide Y (NPY) and insulin in obese women. Neuro Endocrinology Letters 26 293-296.

Barson JR, Karatayev O, Gaysinskaya V, Chang GQ \& Leibowitz SF 2012 Effect of dietary fatty acid composition on food intake, triglycerides, and hypothalamic peptides. Regulatory Peptides 173 13-20. (https:// doi.org/10.1016/j.regpep.2011.08.012)

Bastien P, Procop GW \& Reischl U 2008 Quantitative real-time PCR is not more sensitive than "conventional" PCR. Journal of Clinical Microbiology 46 1897-1900. (https://doi.org/10.1128/ JCM.02258-07)

Boden G 1999 Free fatty acids, insulin resistance, and type 2 diabetes mellitus. Proceedings of the Association of American Physicians 111 241-248. (https://doi.org/10.1046/j.1525-1381.1999.99220.x)

Chemelli RM, Willie JT, Sinton CM, Elmquist JK, Scammell T, Lee C, Richardson JA, Williams SC, Xiong Y, Kisanuki Y, et al. 1999 Narcolepsy in orexin knockout mice: molecular genetics of sleep regulation. Cell 98 437-451. (https://doi.org/10.1016/S00928674(00)81973-X)

Chen L, Zhao Y, Zheng D, Ju S, Shen Y \& Guo L 2013 Orexin A affects INS-1 rat insulinoma cell proliferation via orexin receptor 1 and the AKT signaling pathway. International Journal of Endocrinology 2013 854623. (https://doi.org/10.1155/2013/854623)

Cnop M, Welsh N, Jonas JC, Jorns A, Lenzen S \& Eizirik DL 2005 Mechanisms of pancreatic beta-cell death in type 1 and type 2 diabetes: many differences, few similarities. Diabetes 54 (Supplement 2) S97-S107. (https://doi.org/10.2337/diabetes.54.suppl_2.S97)

Colombo M, Gregersen S, Xiao J \& Hermansen K 2003 Effects of ghrelin and other neuropeptides (CART, MCH, orexin A and B, and GLP-1) on the release of insulin from isolated rat islets. Pancreas 27 161-166. (https://doi.org/10.1097/00006676-200308000-00009)

Cypess AM, Lehman S, Williams G, Tal I, Rodman D, Goldfine AB, Kuo FC, Palmer EL, Tseng YH, Doria A, et al. 2009 Identification and importance of brown adipose tissue in adult humans. New England Journal of Medicine 360 1509-1517. (https://doi.org/10.1056/ NEJMoa0810780)

D'Alessio D 2011 The role of dysregulated glucagon secretion in type 2 diabetes. Diabetes, Obesity and Metabolism 13 (Supplement 1) 126-132. (https://doi.org/10.1111/j.1463-1326.2011.01449.x)

Daniele G, Eldor R, Merovci A, Clarke GD, Xiong J, Tripathy D, Taranova A, Abdul-Ghani M \& DeFronzo RA 2014 Chronic reduction of plasma free fatty acid improves mitochondrial function and whole-body insulin sensitivity in obese and type 2 diabetic individuals. Diabetes 63 2812-2820. (https://doi. org/10.2337/db13-1130)

de Lecea L, Kilduff TS, Peyron C, Gao X, Foye PE, Danielson PE, Fukuhara C, Battenberg EL, Gautvik VT, Bartlett FS 2nd, et al. 1998 The hypocretins: hypothalamus-specific peptides with neuroexcitatory activity. PNAS 95 322-327. (https://doi.org/10.1073/ pnas.95.1.322)

de Souza CJ, Eckhardt M, Gagen K, Dong M, Chen W, Laurent D \& Burkey BF 2001 Effects of pioglitazone on adipose tissue remodeling within the setting of obesity and insulin resistance. Diabetes $\mathbf{5 0}$ 1863-1871. (https://doi.org/10.2337/diabetes.50.8.1863)

Digby JE, Chen J, Tang JY, Lehnert H, Matthews RN \& Randeva HS 2006 Orexin receptor expression in human adipose tissue: effects of orexin-A and orexin-B. Journal of Endocrinology 191 129-136. (https:// doi.org/10.1677/joe.1.06886)

Ehrstrom M, Naslund E, Levin F, Kaur R, Kirchgessner AL, Theodorsson E \& Hellstrom PM 2004 Pharmacokinetic profile of orexin A and effects on plasma insulin and glucagon in the rat. Regulatory Peptides $\mathbf{1 1 9}$ 209-212. (https://doi.org/10.1016/j.regpep.2004.02.004)

Ehrstrom M, Gustafsson T, Finn A, Kirchgessner A, Gryback P, Jacobsson H, Hellstrom PM \& Naslund E 2005 Inhibitory effect of exogenous orexin a on gastric emptying, plasma leptin, and the 
distribution of orexin and orexin receptors in the gut and pancreas in man. Journal of Clinical Endocrinology and Metabolism 90 2370-2377. (https://doi.org/10.1210/jc.2004-1408)

Frayn KN, Tan GD \& Karpe F 2007 Adipose tissue: a key target for diabetes pathophysiology and treatment? Hormone and Metabolic Research 39 739-742. (https://doi.org/10.1055/s-2007-990270)

Funato H, Tsai AL, Willie JT, Kisanuki Y, Williams SC, Sakurai T \& Yanagisawa M 2009 Enhanced orexin receptor-2 signaling prevents diet-induced obesity and improves leptin sensitivity. Cell Metabolism 9 64-76. (https://doi.org/10.1016/j.cmet.2008.10.010)

Girard J 1997 Is leptin the link between obesity and insulin resistance? Diabetes and Metabolism 23 (Supplement 3) 16-24.

Goncz E, Strowski MZ, Grotzinger C, Nowak KW, Kaczmarek P, Sassek M, Mergler S, El-Zayat BF, Theodoropoulou M, Stalla GK, et al. 2008 Orexin-A inhibits glucagon secretion and gene expression through a Foxo1-dependent pathway. Endocrinology 149 1618-1626. (https:// doi.org/10.1210/en.2007-1257)

Grossman SP 1986 The role of glucose, insulin and glucagon in the regulation of food intake and body weight. Neuroscience and Biobehavioral Reviews 10 295-315. (https://doi.org/10.1016/01497634(86)90015-1)

Hara J, Beuckmann CT, Nambu T, Willie JT, Chemelli RM, Sinton CM, Sugiyama F, Yagami K, Goto K, Yanagisawa M, et al. 2001 Genetic ablation of orexin neurons in mice results in narcolepsy, hypophagia, and obesity. Neuron 30 345-354. (https://doi.org/10.1016/S08966273(01)00293-8)

Haynes AC, Chapman H, Taylor C, Moore GB, Cawthorne MA, Tadayyon M, Clapham JC \& Arch JR 2002 Anorectic, thermogenic and anti-obesity activity of a selective orexin-1 receptor antagonist in ob/ ob mice. Regulatory Peptides 104 153-159. (https://doi.org/10.1016/ S0167-0115(01)00358-5)

Heckemeyer CM, Barker J, Duckworth WC \& Solomon SS 1983 Studies of the biological effect and degradation of glucagon in the rat perifused isolated adipose cell. Endocrinology 113 270-276. (https://doi. org/10.1210/endo-113-1-270)

Henquin JC \& Rahier J 2011 Pancreatic alpha cell mass in European subjects with type 2 diabetes. Diabetologia 54 1720-1725. (https://doi. org/10.1007/s00125-011-2118-4)

Honda Y, Doi Y, Ninomiya R \& Ninomiya C 1986 Increased frequency of non-insulin-dependent diabetes mellitus among narcoleptic patients. Sleep 9 254-259. (https://doi.org/10.1093/sleep/9.1.254)

Hui H, Dotta F, Di Mario U \& Perfetti R 2004 Role of caspases in the regulation of apoptotic pancreatic islet beta-cells death. Journal of Cellular Physiology 200 177-200. (https://doi.org/10.1002/ jcp.20021)

Hummel KP, Dickie MM \& Coleman DL 1966 Diabetes, a new mutation in the mouse. Science 153 1127-1128. (https://doi.org/10.1126/ science.153.3740.1127)

Ida T, Nakahara K, Murakami T, Hanada R, Nakazato M \& Murakami N 2000 Possible involvement of orexin in the stress reaction in rats. Biochemical and Biophysical Research Communications 270 318-323. (https://doi.org/10.1006/bbrc.2000.2412)

Ingalls AM, Dickie MM \& Snell GD 1950 Obese, a new mutation in the house mouse. Journal of Heredity 41 317-318. (https://doi. org/10.1093/oxfordjournals.jhered.a106073)

Jiang S, Zhang E, Zhang R \& Li X 2016 Altered activity patterns of transcription factors induced by endoplasmic reticulum stress. BMC Biochemistry 17 8. (https://doi.org/10.1186/s12858-016-0060-2)

Johren O, Neidert SJ, Kummer M, Dendorfer A \& Dominiak P 2001 Prepro-orexin and orexin receptor mRNAs are differentially expressed in peripheral tissues of male and female rats. Endocrinology 142 3324-3331. (https://doi.org/10.1210/endo.142.8.8299)

Kaczmarek P, Skrzypski M, Pruszynska-Oszmalek E, Sassek M, Kolodziejski PA, Billert M, Szczepankiewicz D, Wojciechowicz T, Maechler P, Nowak KW, et al. 2017 Chronic orexin-A (hypocretin-1) treatment of type 2 diabetic rats improves glucose control and beta-cell functions. Journal of Physiology and Pharmacology 68 669-681.

Kirchgessner AL \& Liu M 1999 Orexin synthesis and response in the gut. Neuron 24 941-951. (https://doi.org/10.1016/S08966273(00)81041-7)

Kukkonen JP 2014 Lipid signaling cascades of orexin/hypocretin receptors. Biochimie 96 158-165. (https://doi.org/10.1016/j. biochi.2013.06.015)

Kukkonen JP \& Leonard CS 2014 Orexin/hypocretin receptor signalling cascades. British Journal of Pharmacology 171 314-331.

Liao W, Nguyen MT, Yoshizaki T, Favelyukis S, Patsouris D, Imamura T, Verma IM \& Olefsky JM 2007 Suppression of PPAR-gamma attenuates insulin-stimulated glucose uptake by affecting both GLUT1 and GLUT4 in 3T3-L1 adipocytes. American Journal of Physiology: Endocrinology and Metabolism 293 E219-E227. (https://doi. org/10.1152/ajpendo.00695.2006)

Lin L, Faraco J, Li R, Kadotani H, Rogers W, Lin X, Qiu X, de Jong PJ, Nishino S \& Mignot E 1999 The sleep disorder canine narcolepsy is caused by a mutation in the hypocretin (orexin) receptor 2 gene. Cell 98 365-376. (https://doi.org/10.1016/S00928674(00)81965-0)

Lindsay RS, Funahashi T, Hanson RL, Matsuzawa Y, Tanaka S, Tataranni PA, Knowler WC \& Krakoff J 2002 Adiponectin and development of type 2 diabetes in the Pima Indian population. Lancet 360 57-58. (https://doi.org/10.1016/S0140-6736(02)09335-2)

Lubkin M \& Stricker-Krongrad A 1998 Independent feeding and metabolic actions of orexins in mice. Biochemical and Biophysical Research Communications 253 241-245.

Luo J, Quan J, Tsai J, Hobensack CK, Sullivan C, Hector R \& Reaven GM 1998 Nongenetic mouse models of non-insulin-dependent diabetes mellitus. Metabolism 47 663-668. (https://doi.org/10.1016/S00260495(98)90027-0)

MacDonald PE, Joseph JW \& Rorsman P 2005 Glucose-sensing mechanisms in pancreatic beta-cells. Philosophical Transactions of the Royal Society of London: Series B, Biological Sciences 360 2211-2225. (https://doi.org/10.1098/rstb.2005.1762)

Maeda N, Takahashi M, Funahashi T, Kihara S, Nishizawa H, Kishida K, Nagaretani H, Matsuda M, Komuro R, Ouchi N, et al. 2001 PPARgamma ligands increase expression and plasma concentrations of adiponectin, an adipose-derived protein. Diabetes 50 2094-2099. (https://doi.org/10.2337/diabetes.50.9.2094)

Maedler K \& Donath MY 2004 Beta-cells in type 2 diabetes: a loss of function and mass. Hormone Research 62 (Supplement 3) 67-73. (https://doi.org/10.1159/000080503)

Makki K, Froguel P \& Wolowczuk I 2013 Adipose tissue in obesityrelated inflammation and insulin resistance: cells, cytokines, and chemokines. ISRN Inflammation 2013 139239. (https://doi. org/10.1155/2013/139239)

Malendowicz LK, Tortorella C \& Nussdorfer GG 1999 Orexins stimulate corticosterone secretion of rat adrenocortical cells, through the activation of the adenylate cyclase-dependent signaling cascade. Journal of Steroid Biochemistry and Molecular Biology 70 185-188. (https://doi.org/10.1016/S0960-0760(99)00110-7)

Marcus JN, Aschkenasi CJ, Lee CE, Chemelli RM, Saper CB, Yanagisawa M \& Elmquist JK 2001 Differential expression of orexin receptors 1 and 2 in the rat brain. Journal of Comparative Neurology 435 6-25. (https:// doi.org/10.1002/cne.1190)

Martins L, Seoane-Collazo P, Contreras C, Gonzalez-Garcia I, MartinezSanchez N, Gonzalez F, Zalvide J, Gallego R, Dieguez C, Nogueiras R, et al. 2016 A functional link between AMPK and orexin mediates the effect of BMP8B on energy balance. Cell Reports 16 2231-2242. (https://doi.org/10.1016/j.celrep.2016.07.045)

Mohammed M, Ootsuka Y, Yanagisawa M \& Blessing W 2014 Reduced brown adipose tissue thermogenesis during environmental interactions in transgenic rats with ataxin-3-mediated ablation of hypothalamic orexin neurons. American Journal of Physiology: 
Regulatory, Integrative and Comparative Physiology 307 R978-R989. (https://doi.org/10.1152/ajpregu.00260.2014)

Monda M, Viggiano A, Mondola P \& De Luca V 2001 Inhibition of prostaglandin synthesis reduces hyperthermic reactions induced by hypocretin-1/orexin A. Brain Research 909 68-74. (https://doi. org/10.1016/S0006-8993(01)02606-3)

Muise ES, Azzolina B, Kuo DW, El-Sherbeini M, Tan Y, Yuan X, Mu J, Thompson JR, Berger JP \& Wong KK 2008 Adipose fibroblast growth factor 21 is up-regulated by peroxisome proliferator-activated receptor gamma and altered metabolic states. Molecular Pharmacology $\mathbf{7 4}$ 403-412. (https://doi.org/10.1124/mol.108.044826)

Nakabayashi M, Suzuki T, Takahashi K, Totsune K, Muramatsu Y, Kaneko C, Date F, Takeyama J, Darnel AD, Moriya T, et al. 2003 Orexin-A expression in human peripheral tissues. Molecular and Cellular Endocrinology 205 43-50. (https://doi.org/10.1016/S03037207(03)00206-5)

Nicholls DG, Bernson VS \& Heaton GM 1978 The identification of the component in the inner membrane of brown adipose tissue mitochondria responsible for regulating energy dissipation. Experientia Supplementum 32 89-93.

Nishino S, Ripley B, Overeem S, Lammers GJ \& Mignot E 2000 Hypocretin (orexin) deficiency in human narcolepsy. Lancet $\mathbf{3 5 5}$ 39-40. (https://doi.org/10.1016/S0140-6736(99)05582-8)

Nivala AM, Reese L, Frye M, Gentile CL \& Pagliassotti MJ 2013 Fatty acid-mediated endoplasmic reticulum stress in vivo: differential response to the infusion of Soybean and Lard Oil in rats. Metabolism 62 753-760. (https://doi.org/10.1016/j.metabol.2012.12.001)

Novak CM \& Levine JA 2009 Daily intraparaventricular orexin-A treatment induces weight loss in rats. Obesity 17 1493-1498. (https:// doi.org/10.1038/oby.2009.91)

Nowak KW, Mackowiak P, Switonska MM, Fabis M \& Malendowicz LK 2000 Acute orexin effects on insulin secretion in the rat: in vivo and in vitro studies. Life Sciences 66 449-454. (https://doi.org/10.1016/ S0024-3205(99)00611-6)

Nowak KW, Strowski MZ, Switonska MM, Kaczmarek P, Singh V, Fabis M, Mackowiak P, Nowak M \& Malendowicz LK 2005 Evidence that orexins A and B stimulate insulin secretion from rat pancreatic islets via both receptor subtypes. International Journal of Molecular Medicine 15 969-972.

Ouchi N, Parker JL, Lugus JJ \& Walsh K 2011 Adipokines in inflammation and metabolic disease. Nature Reviews Immunology 11 85-97. (https:// doi.org/10.1038/nri2921)

Ouedraogo R, Naslund E \& Kirchgessner AL 2003 Glucose regulates the release of orexin-a from the endocrine pancreas. Diabetes 52 111-117. (https://doi.org/10.2337/diabetes.52.1.111)

Ouellet V, Labbe SM, Blondin DP, Phoenix S, Guerin B, Haman F, Turcotte EE, Richard D \& Carpentier AC 2012 Brown adipose tissue oxidative metabolism contributes to energy expenditure during acute cold exposure in humans. Journal of Clinical Investigation 122 545-552. (https://doi.org/10.1172/JCI60433)

Park JH, Shim HM, Na AY, Bae JH, Im SS \& Song DK 2015 Orexin A regulates plasma insulin and leptin levels in a time-dependent manner following a glucose load in mice. Diabetologia 58 1542-1550. (https://doi.org/10.1007/s00125-015-3573-0)

Perea A, Clemente F, Martinell J, Villanueva-Penacarrillo ML \& Valverde I 1995 Physiological effect of glucagon in human isolated adipocytes. Hormone and Metabolic Research 27 372-375. (https://doi. org/10.1055/s-2007-979981)

Perez-Leighton CE, Boland K, Teske JA, Billington C \& Kotz CM 2012 Behavioral responses to orexin, orexin receptor gene expression, and spontaneous physical activity contribute to individual sensitivity to obesity. American Journal of Physiology: Endocrinology and Metabolism 303 E865-E874. (https://doi.org/10.1152/ajpendo.00119.2012)

Perez-Leighton CE, Boland K, Billington CJ \& Kotz CM 2013 High and low activity rats: elevated intrinsic physical activity drives resistance to diet-induced obesity in non-bred rats. Obesity 21 353-360. (https:// doi.org/10.1002/oby.20045)

Pino MF, Divoux A, Simmonds AV, Smith SR \& Sparks LM 2017 Investigating the effects of Orexin-A on thermogenesis in human deep neck brown adipose tissue. International Journal of Obesity $\mathbf{4 1}$ 1646-1653.

Prentki M \& Matschinsky FM 1987 Ca2+, cAMP, and phospholipidderived messengers in coupling mechanisms of insulin secretion. Physiological Reviews 67 1185-1248. (https://doi.org/10.1152/ physrev.1987.67.4.1185)

Prentki M \& Nolan CJ 2006 Islet beta cell failure in type 2 diabetes. Journal of Clinical Investigation 116 1802-1812. (https://doi. org/10.1172/JCI29103)

Pruszynska-Oszmalek E, Kolodziejski P, Kaczmarek P, Sassek M, Szczepankiewicz D, Mikula R \& Nowak K 2018 Orexin A but not orexin B regulates lipid metabolism and leptin secretion in isolated porcine adipocytes. Domestic Animal Endocrinology 63 59-68. (https:// doi.org/10.1016/j.domaniend.2017.12.003)

Ramanathan L \& Siegel JM 2014 Gender differences between hypocretin/ orexin knockout and wild type mice: age, body weight, body composition, metabolic markers, leptin and insulin resistance. Journal of Neurochemistry 131 615-624. (https://doi.org/10.1111/jnc.12840)

Reed MJ, Meszaros K, Entes LJ, Claypool MD, Pinkett JG, Gadbois TM \& Reaven GM 2000 A new rat model of type 2 diabetes: the fat-fed, streptozotocin-treated rat. Metabolism 49 1390-1394. (https://doi. org/10.1053/meta.2000.17721)

Richard D, Carpentier AC, Dore G, Ouellet V \& Picard F 2010 Determinants of brown adipocyte development and thermogenesis. International Journal of Obesity 34 (Supplement 2) S59-S66. (https:// doi.org/10.1038/ijo.2010.241)

Rivera L, Moron R, Sanchez M, Zarzuelo A \& Galisteo M 2008 Quercetin ameliorates metabolic syndrome and improves the inflammatory status in obese Zucker rats. Obesity 16 2081-2087. (https://doi. org/10.1038/oby.2008.315)

Rosen ED \& Spiegelman BM 2006 Adipocytes as regulators of energy balance and glucose homeostasis. Nature 444 847-853. (https://doi. org/10.1038/nature05483)

Russell SH, Small CJ, Sunter D, Morgan I, Dakin CL, Cohen MA \& Bloom SR 2002 Chronic intraparaventricular nuclear administration of orexin A in male rats does not alter thyroid axis or uncoupling protein-1 in brown adipose tissue. Regulatory Peptides 104 61-68. (https://doi.org/10.1016/S0167-0115(01)00349-4)

Sakurai T, Amemiya A, Ishii M, Matsuzaki I, Chemelli RM, Tanaka H, Williams SC, Richardson JA, Kozlowski GP, Wilson S, et al. 1998 Orexins and orexin receptors: a family of hypothalamic neuropeptides and $\mathrm{G}$ protein-coupled receptors that regulate feeding behavior. Cell 92 573-585. (https://doi.org/10.1016/S00928674(00)80949-6)

Sassek M, Pruszynska-Oszmalek E \& Nowak KW 2017 Orexin A modulates endocrine function and viability of porcine pancreatic islets. Journal of Physiology and Pharmacology 68 815-821.

Schuld A, Hebebrand J, Geller F \& Pollmacher T 2000 Increased bodymass index in patients with narcolepsy. Lancet 355 1274-1275. (https://doi.org/10.1016/S0140-6736(05)74704-8)

Sears B \& Perry M 2015 The role of fatty acids in insulin resistance. Lipids in Health and Disease 14 121. (https://doi.org/10.1186/s12944-0150123-1)

Sellayah D \& Sikder D 2012 Orexin receptor-1 mediates brown fat developmental differentiation. Adipocyte 1 58-63. (https://doi. org/10.4161/adip.18965)

Sellayah D \& Sikder D 2013 Orexin restores aging-related brown adipose tissue dysfunction in male mice. Endocrinology 155 485-501. (https:// doi.org/10.1210/en.2013-1629)

Sellayah D, Bharaj P \& Sikder D 2011 Orexin is required for brown adipose tissue development, differentiation, and function.
(C) 2018 Society for Endocrinology Published by Bioscientifica Ltd. Printed in Great Britain 
Cell Metabolism 14 478-490. (https://doi.org/10.1016/j. cmet.2011.08.010)

Sharma AM \& Staels B 2007 Review: peroxisome proliferator-activated receptor gamma and adipose tissue--understanding obesity-related changes in regulation of lipid and glucose metabolism. Journal of Clinical Endocrinology and Metabolism 92 386-395. (https://doi. org/10.1210/jc.2006-1268)

Shen Y, Zhao Y, Zheng D, Chang X, Ju S \& Guo L 2013 Effects of orexin A on GLUT4 expression and lipid content via MAPK signaling in 3T3-L1 adipocytes. Journal of Steroid Biochemistry and Molecular Biology 138 376-383. (https://doi.org/10.1016/j.jsbmb.2013.07.005)

Shiuchi T, Haque MS, Okamoto S, Inoue T, Kageyama H, Lee S, Toda C, Suzuki A, Bachman ES, Kim YB, et al. 2009 Hypothalamic orexin stimulates feeding-associated glucose utilization in skeletal muscle via sympathetic nervous system. Cell Metabolism 10 466-480. (https:// doi.org/10.1016/j.cmet.2009.09.013)

Skrzypski M, TLe T, Kaczmarek P, Pruszynska-Oszmalek E, Pietrzak P, Szczepankiewicz D, Kolodziejski PA, Sassek M, Arafat A, Wiedenmann B, et al. 2011 Orexin A stimulates glucose uptake, lipid accumulation and adiponectin secretion from 3T3-L1 adipocytes and isolated primary rat adipocytes. Diabetologia 54 1841-1852. (https:// doi.org/10.1007/s00125-011-2152-2)

Skrzypski M, Kaczmarek P, Le TT, Wojciechowicz T, PruszynskaOszmalek E, Szczepankiewicz D, Sassek M, Arafat A, Wiedenmann B, Nowak KW, et al. 2012 Effects of orexin A on proliferation, survival, apoptosis and differentiation of 3T3-L1 preadipocytes into mature adipocytes. FEBS Letters 586 4157-4164. (https://doi.org/10.1016/j. febslet.2012.10.013)

Skrzypski M, Khajavi N, Mergler S, Billert M, Szczepankiewicz D, Wojciechowicz T, Nowak KW \& Strowski MZ 2016 Orexin A modulates INS-1E cell proliferation and insulin secretion via extracellular signal-regulated kinase and transient receptor potential channels. Journal of Physiology and Pharmacology 67 643-652.

Smart D, Jerman JC, Brough SJ, Rushton SL, Murdock PR, Jewitt F, Elshourbagy NA, Ellis CE, Middlemiss DN \& Brown F 1999 Characterization of recombinant human orexin receptor pharmacology in a Chinese hamster ovary cell-line using FLIPR. British Journal of Pharmacology 128 1-3. (https://doi.org/10.1038/ sj.bjp.0702780)

Smith RE \& Horwitz BA 1969 Brown fat and thermogenesis. Physiological Reviews 49 330-425. (https://doi.org/10.1152/ physrev.1969.49.2.330)

Steiner DJ, Kim A, Miller K \& Hara M 2010 Pancreatic islet plasticity: interspecies comparison of islet architecture and composition. Islets 2 135-145. (https://doi.org/10.4161/isl.2.3.11815)

Stofkova A 2010 Resistin and visfatin: regulators of insulin sensitivity, inflammation and immunity. Endocrine Regulations 44 25-36. (https:// doi.org/10.4149/endo_2010_01_25)

Switonska MM, Kaczmarek P, Malendowicz LK \& Nowak KW 2002 Orexins and adipoinsular axis function in the rat. Regulatory Peptides 104 69-73. (https://doi.org/10.1016/S0167-0115(01)00350-0)

Tajik N, Keshavarz SA, Masoudkabir F, Djalali M, Sadrzadeh-Yeganeh HH, Eshraghian MR, Chamary M, Ahmadivand Z, Yazdani T \& Javanbakht MH 2013 Effect of diet-induced weight loss on inflammatory cytokines in obese women. Journal of Endocrinological Investigation 36 211-215. (https://doi.org/10.3275/8465)

Takahashi Y, Zhang W, Sameshima K, Kuroki C, Matsumoto A, Sunanaga J, Kono Y, Sakurai T, Kanmura Y \& Kuwaki T 2013 Orexin neurons are indispensable for prostaglandin E2-induced fever and defence against environmental cooling in mice. Journal of Physiology 591 5623-5643. (https://doi.org/10.1113/ jphysiol.2013.261271)

Tomasik PJ, Spodaryk M \& Sztefko K 2004 Plasma concentrations of orexins in children. Annals of Nutrition and Metabolism 48 215-220. (https://doi.org/10.1159/000080453)
Tontonoz P, Hu E, Graves RA, Budavari AI \& Spiegelman BM $1994 a$ mPPAR gamma 2: tissue-specific regulator of an adipocyte enhancer. Genes and Development 8 1224-1234. (https://doi.org/10.1101/ gad.8.10.1224)

Tontonoz P, Hu E \& Spiegelman BM 1994b Stimulation of adipogenesis in fibroblasts by PPAR gamma 2, a lipid-activated transcription factor. Cell 79 1147-1156. (https://doi.org/10.1016/00928674(94)90006-X)

Tsuneki H, Sugihara Y, Honda R, Wada T, Sasaoka T \& Kimura I 2002 Reduction of blood glucose level by orexins in fasting normal and streptozotocin-diabetic mice. European Journal of Pharmacology 448 245-252. (https://doi.org/10.1016/S0014-2999(02)01936-2)

Tsuneki H, Murata S, Anzawa Y, Soeda Y, Tokai E, Wada T, Kimura I, Yanagisawa M, Sakurai T \& Sasaoka T 2008 Age-related insulin resistance in hypothalamus and peripheral tissues of orexin knockout mice. Diabetologia 51 657-667. (https://doi.org/10.1007/s00125-0080929-8)

Tupone D, Madden CJ, Cano G \& Morrison SF 2011 An orexinergic projection from perifornical hypothalamus to raphe pallidus increases rat brown adipose tissue thermogenesis. Journal of Neuroscience $\mathbf{3 1}$ 15944-15955. (https://doi.org/10.1523/JNEUROSCI.3909-11.2011)

Walker JN, Ramracheya R, Zhang Q, Johnson PR, Braun M \& Rorsman P 2011 Regulation of glucagon secretion by glucose: paracrine, intrinsic or both? Diabetes, Obesity and Metabolism 13 (Supplement 1) 95-105. (https://doi.org/10.1111/j.1463-1326.2011.01450.x)

Wojciechowicz T, Skrzypski M, Szczepankiewicz D, Hertig I, Kolodziejski PA, Billert M, Strowski MZ \& Nowak KW 2016 Original research: orexins A and B stimulate proliferation and differentiation of porcine preadipocytes. Experimental Biology and Medicine 241 1786-1795. (https://doi.org/10.1177/1535370216649261)

Xu C, He J, Jiang H, Zu L, Zhai W, Pu S \& Xu G 2009 Direct effect of glucocorticoids on lipolysis in adipocytes. Molecular Endocrinology 23 1161-1170. (https://doi.org/10.1210/me.2008-0464)

Yamauchi T, Kamon J, Waki H, Terauchi Y, Kubota N, Hara K, Mori Y, Ide T, Murakami K, Tsuboyama-Kasaoka N, et al. 2001 The fat-derived hormone adiponectin reverses insulin resistance associated with both lipoatrophy and obesity. Nature Medicine 7 941-946. (https://doi. org/10.1038/90984)

Yilmaz E, Celik O, Celik N, Celik E, Turkcuoglu I, Simsek Y, Minareci Y, Boz M \& Aydin S 2013 Maternal and fetal serum orexin-A levels in gestational diabetes mellitus. Journal of Obstetrics and Gynaecology Research 39 139-145. (https://doi.org/10.1111/j.14470756.2012.01955.x)

Yoshimichi G, Yoshimatsu H, Masaki T \& Sakata T 2001 Orexin-A regulates body temperature in coordination with arousal status. Experimental Biology and Medicine 226 468-476. (https://doi. org/10.1177/153537020122600513)

Zarifkar M, Noshad S, Shahriari M, Afarideh M, Khajeh E, Karimi Z, Ghajar A \& Esteghamati A 2017 Inverse association of peripheral orexin-A with insulin resistance in type 2 diabetes mellitus: a randomized clinical trial. Review of Diabetic Studies 14 301-310. (https://doi.org/10.1900/RDS.2017.14.301)

Zhang W, Sunanaga J, Takahashi Y, Mori T, Sakurai T, Kanmura Y \& Kuwaki T 2010a Orexin neurons are indispensable for stress-induced thermogenesis in mice. Journal of Physiology $\mathbf{5 8 8} 4117-4129$. (https:// doi.org/10.1113/jphysiol.2010.195099)

Zhang Z, Li Q, Liu F, Sun Y \& Zhang J $2010 b$ Prevention of dietinduced obesity by safflower oil: insights at the levels of PPARalpha, orexin, and ghrelin gene expression of adipocytes in mice. Acta Biochimica et Biophysica Sinica 42 202-208. (https://doi. org/10.1093/abbs/gmq010)

Zheng H, Patterson LM \& Berthoud HR 2005 Orexin-A projections to the caudal medulla and orexin-induced c-Fos expression, food intake, and autonomic function. Journal of Comparative Neurology 485 127-142. (https://doi.org/10.1002/cne.20515)
() 2018 Society for Endocrinology Published by Bioscientifica Ltd. Printed in Great Britain 
Ziccardi P, Nappo F, Giugliano G, Esposito K, Marfella R, Cioffi M, D'Andrea F, Molinari AM \& Giugliano D 2002 Reduction of inflammatory cytokine concentrations and improvement of endothelial functions in obese women after weight loss over one year. Circulation 105 804-809. (https://doi.org/10.1161/hc0702.104279)
Zwirska-Korczala K, Adamczyk-Sowa M, Sowa P, Pilc K, Suchanek R, Pierzchala K, Namyslowski G, Misiolek M, Sodowski K, Kato I, et al. 2007 Role of leptin, ghrelin, angiotensin II and orexins in 3T3 L1 preadipocyte cells proliferation and oxidative metabolism. Journal of Physiology and Pharmacology 58 (Supplement 1) 53-64.

Received in final form 17 February 2018

Accepted 30 May 2018

Accepted Preprint published online 30 May 2018 